\title{
Comparison Between the Concrete, Sand, Clay, Water and the Paraffin like Materials of Heat Storage for the Solar Water Heaters
}

\author{
Romdhane Ben Slama, Raouf Abdel Moumen, Mohamed Elgoul \\ Departemenet of Electromecanic, ISSAT Gabes, University of Gabes, Gabes, Tunisia \\ Email address: \\ romdhaneb.slama@gmail.com (R. B. Slama)
}

\section{To cite this article:}

Romdhane Ben Slama, Raouf Abdel Moumen., Mohamed Elgoul. Comparison between the Concrete, Sand, Clay, Water and the Paraffin Like Materials of Heat Storage for the Solar Water Heaters. International Journal of Electrical Components and Energy Conversion. Vol. 3, No. 2, 2017, pp. 21-25. doi: 10.11648/j.ijecec.20170302.11

Received: November 30, 2016; Accepted: December 9, 2016; Published: May 19, 2017

\begin{abstract}
Solar energy, though renewable, still has a handicap of heat storage, particularly for the solar water heaters with integrated storage. Indeed, these latter present a significant night cooling. The storage material nature can influence the lifespan of the storage tanks, the quantity of stored heat and its speed of restitution. We compare here five materials for the heat storage which are sand, concrete, clay, Phase Change Material (PCM) and water like element of reference for comparisons. As for the PCM used here, it is paraffin sold in the trade, though other materials admit an enthalpy of higher fusion. If during the diurnal heating, the PCM does not reach the highest temperatures, it is because received solar energy is used for its change of state.However, from a viewpoint amount of stored heat, PCM is the best view of its high latent heat. Also for well as night cooling, the PCM keeps the temperature elevated.
\end{abstract}

Keywords: Water Heating, Solar Energy, Integrated Storage Collector, Storage Material, Concrete, Sand, Clay, Paraffin, Water

\section{Introduction}

In the national and international context, solar energy is able to play a significant role in the energy saving and the environmental protection. Among the various applications of this renewable energy, solar water heater are most widespread because their simplicity and the high requirements out of domestic hot water. Usually, a solar water heater is composed of two major parts: the solar water collector (the panel) and the heat storage realized by a cumulus filled with water [1-3]. The transfer of heat between the two parts is done either by thermosiphon, or by forced water circulation. However, the problem of heat storage for the solar water heaters has still been raised despite all research efforts, for several decades. Often, the requirements out of hot water are shifted (in dephasing) compared to the solar contributions, on a scale day (day and night) and seasonal (summer and winter). The problem is even more serious (sensitive) for the integrated storage solar collectors (ISSC), especially for the flat ones. Indeed, their night cooling, particularly in winter, brings down lower the temperatures and the performances in general in a significant way.

\section{Bibliographical Study}

The heat storage of the solar water heaters has been studied by several authors. Reddy [4] studied paraffin like material with phase shift MCP as a material of storage in a sensor with integrated storage. In the same way, Rabin et al. [5] investigated on hydrated salt with the same aim than the experiments of Reddy and developed a one-dimensional model to study the process of the system filling. They concluded that this type of system can yield a collection performance of approximately $66 \%$ during winter in BeerSheva, Israel, but that the use of such a system is likely to be limited to special applications, such as space and soil heating greenhouses in arid areas, during winter.

But the problem of heat storage still remains current. Thus, we contribute to solve these problems using 
commentmaterials, which are cheap and with phase change.

Our integrated storage solar collector (ISSC) is composed of an absorber, a glazing, an insulator and a case [6-10]. Deteriorations of the ISSC often take place on the level of the absorber which at the same time plays the role of tank of storage of hot water. The attack is done by corrosion of its material inducing escapes thus and in consequence new expenses of replacement.

The tank storage, usually made of metal is subject to corrosion, is often treated by enameling, or made by stainless still and is protected by a magnesium bar (anodizing). Despite all these precautions, corrosion however occurs after a certain time.

To cure definitively this problem of corrosion, we recommend to exceed traditional storage of heat in the water contained in the metal tank and to replace this water by sand, concrete, clay etc. (cf $\S 2.1$ ). In this storage, the heat exchanger containing some water is integrated there.
Oilshould to be avoided, for safety to prevent fire breakouts reasons.

Paraffin and other materials with phase change will be presented in the paragraph 2-2.

\subsection{Preliminary Thermal Data on Some Materials (Comparison Between Water, Sand, Concrete, Clay and Plaster)}

A preliminary study on the storage material choice enables to make a selection. It is based especially on the thermal conductivity, the thermal specific capacity, the diffusivity and the effusivity (table 1). Our choice was focused on concrete, clay, sand and the water taken as reference. Plaster should to be avoided because it owns the weakest conductivity and thermal effusivity. Concrete and clay are interesting and moreover can be directlymolded, thus doing without being the prone to corrosion and having an expensive metal tank.

Table 1. Properties of some materials- [11-15].

\begin{tabular}{|c|c|c|c|c|c|}
\hline Materials & $\operatorname{Density}\{\rho\}\left(\mathrm{kg} / \mathrm{m}^{3}\right)$ & $\begin{array}{l}\text { Thermal conductivity }\{\lambda\} \\
(W / \text { m.K) }\end{array}$ & $\begin{array}{l}\text { Heat capacity }\{\mathrm{cp}\} \\
\left(\mathrm{J} / \mathrm{kg}^{\circ} \mathrm{C}\right)\end{array}$ & $\begin{array}{l}\text { Diffusivity }\{D\} \\
\left(10^{-6} \mathrm{~m}^{2} / \mathrm{s}\right)\end{array}$ & $\begin{array}{l}\text { Effusivity }\{\mathbf{E}\} \\
\left(\mathbf{J} / \mathbf{m}^{2} \cdot \mathbf{K} . \mathbf{s}^{1} / 2\right)\end{array}$ \\
\hline Concrete & 2300 & 1,75 & 880 & 0.54 & 1940 \\
\hline Clay & 1450 & 1.28 & 880 & 1.00 & 1220 \\
\hline Water & 1000 & 0.607 & 4185 & 0.37 & 1590 \\
\hline Dry Sand & 1650 & 0.27 & 835 & 0.20 & 760 \\
\hline
\end{tabular}

\subsection{Preliminary Thermal Data on Some Phase Change Materials (Comparison Between Water, Sand, Concrete, Clay and Plaster)}

The materials with phase change benefit from the latent heat in addition to significant heat.
In what concerns us here, we are interested in the change of solid-liquid state during the heating and in the change of liquid-solid state during cooling. Our choice is related to organic materials with mixture with intervals of temperature, either paraffin, or fatty acids.

The physical characteristics of paraffin are shown in table 2 .

Table 2. Examples of physical properties of paraffin.

\begin{tabular}{|c|c|c|c|c|}
\hline & \multicolumn{4}{|l|}{ Paraffin } \\
\hline & Tetradecane & Hexadecane & Octadecane & Eicosane \\
\hline Formulate & $\mathrm{C} 14 \mathrm{H} 30$ & $\mathrm{C} 16 \mathrm{H} 34$ & $\mathrm{C} 18 \mathrm{H} 38$ & $\mathrm{C} 2 \mathrm{OH} 42$ \\
\hline Fusion point $\left[{ }^{\circ} \mathrm{C}\right]$ & 5.5 & 16.7 & 28 & 39.6 \\
\hline Enthalpy of fusion $[\mathrm{kJ} / \mathrm{kg}]$ & 226 & 237 & 244 & 247 \\
\hline Thermal conductivity $\left[\mathrm{W} / \mathrm{m} .{ }^{\circ} \mathrm{C}\right]$ & 0.18 & 0.18 & 0.25 & 0.25 \\
\hline Mass heat capacity $\left[\mathrm{kJ} / \mathrm{kg} .{ }^{\circ} \mathrm{C}\right]$ & 2.07 & 2.11 & 2.16 & 2.21 \\
\hline Liquid density $\left[\mathrm{kg} / \mathrm{m}^{3}\right]$ & 771 & 776 & 774 & 778 \\
\hline Vapour Pressure $[\mathrm{Pa}]$ & 133 to $75^{\circ} \mathrm{C}$ & 133 to $105^{\circ} \mathrm{C}$ & 133 to $75^{\circ} \mathrm{C}$ & 133to $100^{\circ} \mathrm{C}$ \\
\hline Surface Tension[N/m] & $27.410^{-3}$ & 3.4 & $27.410^{-3}$ & - \\
\hline Viscosity [cp] & 2.1 & $\ldots$ & 3.4 & $\ldots$ \\
\hline
\end{tabular}

We can differentiate materials according to their thermal properties, in particular their conductivity, heat capacity, diffusivity and effusivity which playing a major role in the storage of solar heat and its restitution to the coolant water contained in the heat exchanger (tables $1 \& 2$ ).

\section{Design and Realization of Five Integrated Storage Solar Collectors}

We study here an auto-storage type solar water-heater, made up of a flat tank painted in black placed inside a trunk. The unit is closed by a simple or double glazing or a double polycarbonate plate (figure 1). 


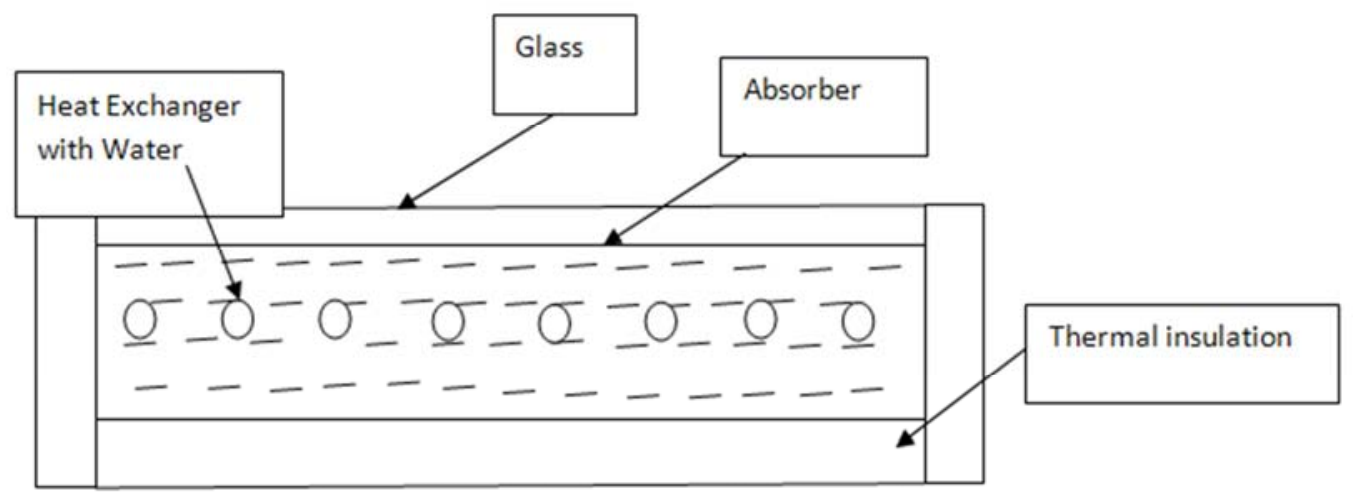

Figure 1. Diagram of an integrated storage solar water heater.

\section{Tests}

\subsection{Experimental Protocol}

The tests were carried out in June 2014, thanks to measuring instruments of precision provided by the National School of Engineering of Gabes, Tunisia. Various climatic parameters were measured such as the ambient temperature, speed of wind, the temperature in the water-heater and the solar flux. The precision of measurements of the temperatures, ensured by digital display panels, is of $\pm 0.5 \mathrm{C}$. For solar flux the precision is of $\pm 2 \%$.

The study of the solar water heaters is made under real conditions of operation. The solar collector is tilted to $45^{\circ}$ and is directed towards the south.
The temperature measurement is made by thermometers with digital display of precision. Measurements begin at 8 am until $6 \mathrm{pm}$, and at each hour the water temperature is recorded, at the inlet and the outlet of all the solar collectors.

\subsection{Tracing of the Curves of Measurement}

a) The curves of the water and ambient temperatures during twenty four hours, for five storage materials: (collectors orientated towards the south, slope of $45^{\circ}$ ) are given in figure 2.

The temperature measurements are taken hour per hour, for the five waterheaters simultaneously and under the same climatic conditions.

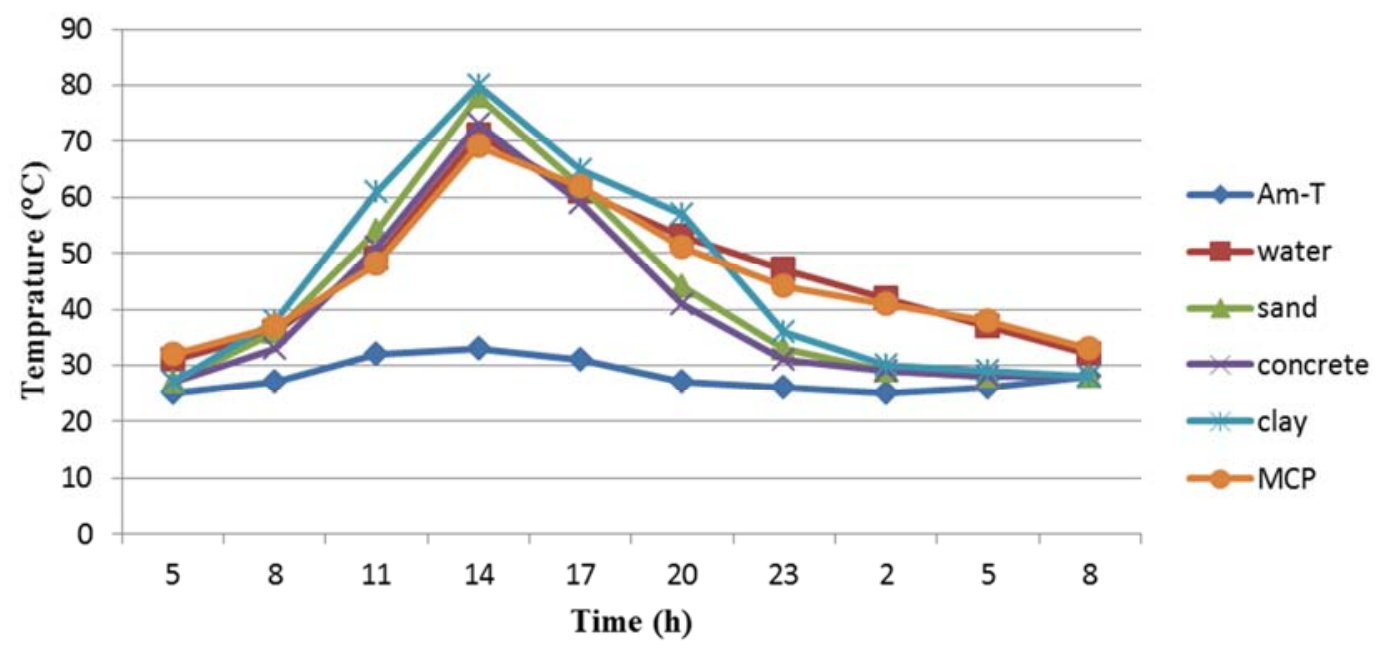

Figure 2. Variation of the water temperature for twenty four hours according to the storage material nature. (Am-T: Ambient temperature; MCP: phase change material).

During diurnal heating, clay and sand heat more, but in night cooling in fact rather and the PCM parks the highest temperature.

The maximum of temperature is reached 1) for PCM with $69^{\circ} \mathrm{C}, 2$ ) for water and concrete with $70^{\circ} \mathrm{C}, 3$ ) for sand with $78^{\circ} \mathrm{C}$, and clay with $80^{\circ} \mathrm{C}$, under an ambient temperature of $30^{\circ} \mathrm{C}$.

The maximum of temperature is reached for 1) clay with $80^{\circ} \mathrm{C}, 2$ ) sand with $78^{\circ} \mathrm{C}, 3$ ) water and concrete with $70^{\circ} \mathrm{C}$, and $\mathrm{PCM}$ with $69^{\circ} \mathrm{C}$, under an ambient temperature of $30^{\circ} \mathrm{C}$.

Hunce, we can note that the ambient temperature has a great effect on the heat losses of the solar collectors during the night, especially under a clear sky.

b) The water temperature and of the ambient one are recorded during three days for five storage materials:(collectors orientated towards the south, slope of $45^{\circ}$ ) as depicted in figure 3 . 


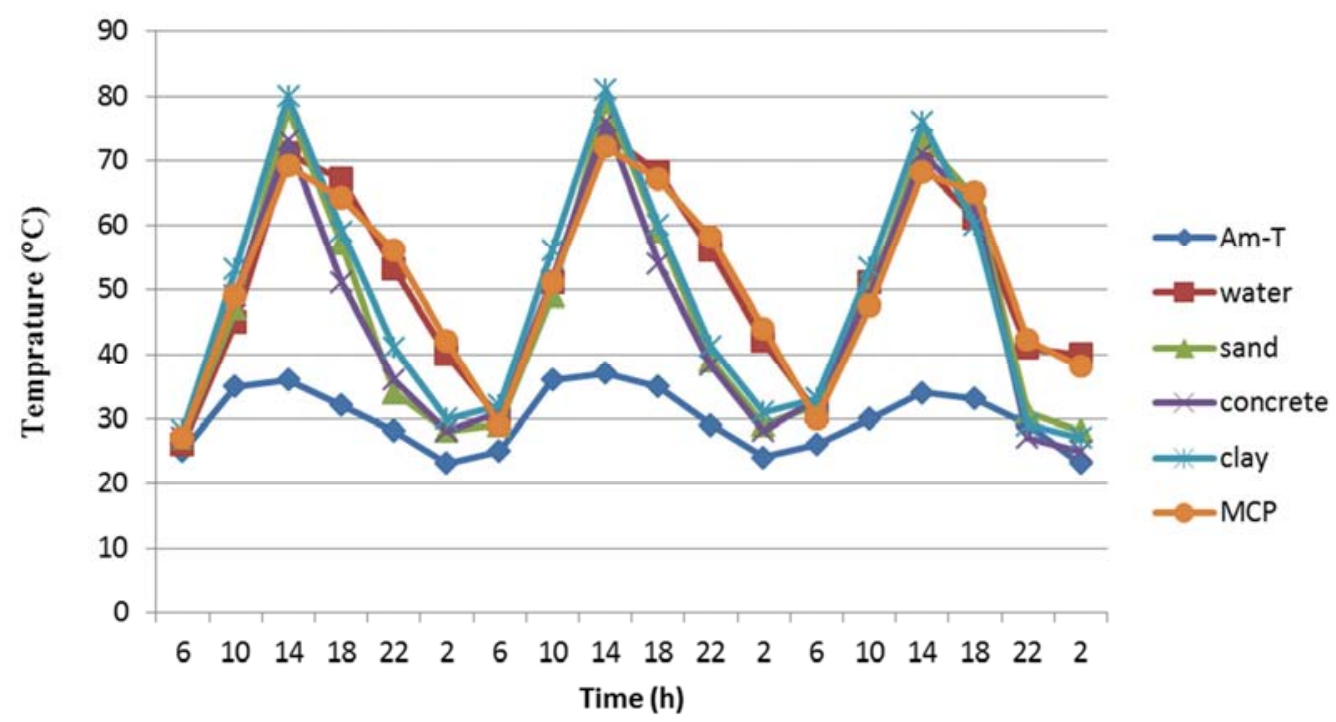

Figure 3. Variation of the storage materials temperatures during three days (5 to 7 June 2013).

According to figure 3 , the temperature of the water contained in storage quickly increases during the day, then night cooling slowly lowers the water temperature.

The water of storage has much inertia to heat (high $\mathrm{Cp}$ ) in the day, and quickly cools in the night because of its strong thermal conductivity with the absorber which cools by radiation towards the sky.

As for storage in sand and the concrete, their thermal inertia and their diffusivity are less significant than those of water, they heat more and their cooling is less significant because of their strong density.

\subsection{Thermal Loss Coefficient Of The Collector And Stored Heat Temperatures Quantity}

With the aim of comparing the temperature evolution between materials during the night one can calculate the thermal loss coefficients $\mathrm{U}\left(\mathrm{W} / \mathrm{m}^{2}{ }^{\circ} \mathrm{C}\right)$.

With: $\mathrm{U}=\frac{\rho . c p . v}{\Delta t . S} \ln \frac{(\mathrm{Ti}-\mathrm{Tambi})}{(\mathrm{Tf}-\mathrm{Tambf})}$

\begin{tabular}{ll}
\hline Material & $\mathbf{U}\left(\mathbf{W m}^{-20} \mathbf{C}^{-1}\right)$ \\
\hline concrete & 9 \\
Sand & 5 \\
clay & 5 \\
PCM & 2.2 \\
Water & 3 \\
\hline
\end{tabular}

This loss has an influence on the heat quantity stored in materials.

With:Q/m=cp. $\Delta \mathrm{T}+\mathrm{L}^{*} \quad \mathrm{~L} *$ : latent heat ofPCM=243kJ $/ \mathrm{kg}$ )

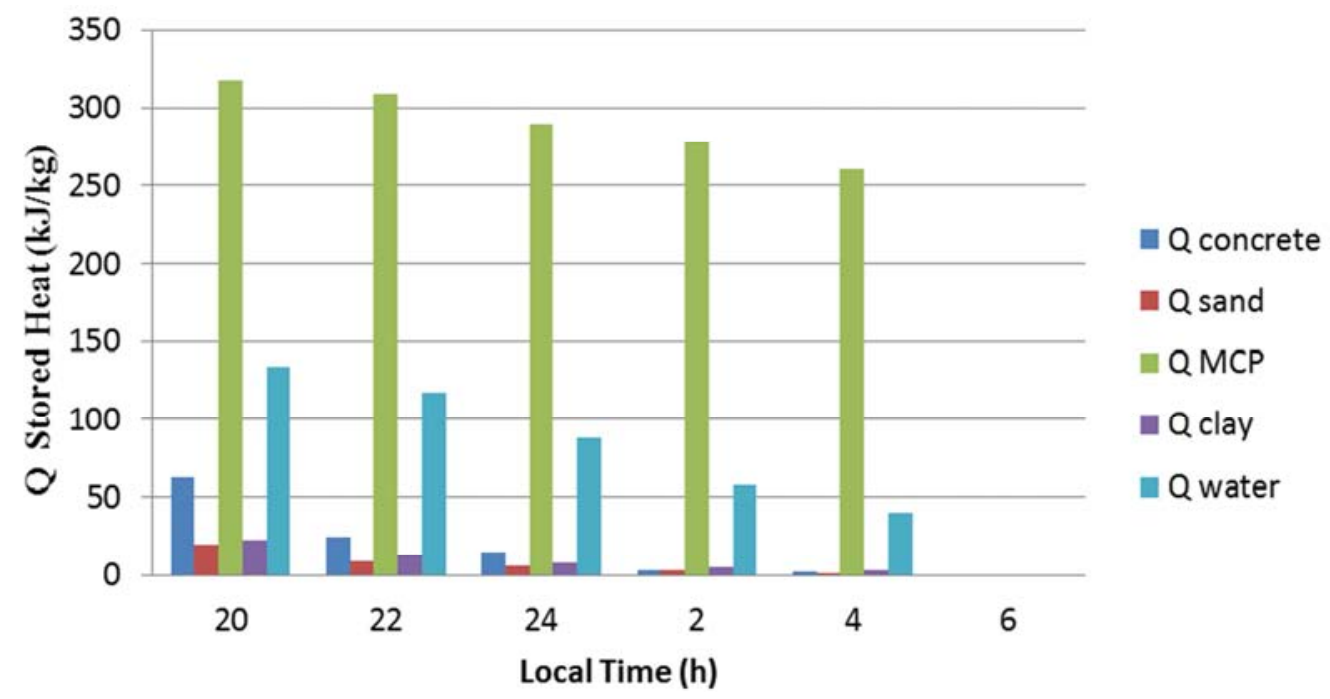

Figure 4. Night decease of the stored heat quantity. 


\section{Interpretation}

By comparison of the thermal loss coefficients of the solar collectors, one retains that the PCMand water have weak losses during night which has a direct influence on their storage heat capacity.

\section{Conclusionsand Prospects}

The water usually used for the heat storage has the handicap to corrode the metal walls, usually made out of steel. Even the most effective treatments do not resist after few years of use. Other studied materials can replace water, such as concrete, clay and even sand. The phase change materials can be promising since they allow more stored heat. Paraffin tested in this present work is part of them. The quantity of heat stored by paraffin is more than the double of that stored in water, and even more for other tested materials.

\section{Nomenclature}

A: Useful surface area of the collector $\mathrm{m}^{2}$

C: Specific heat of material $\mathrm{J} / \mathrm{Kg} \mathrm{K}$

D: Diffusivity $\mathrm{m}^{2} / \mathrm{s}$

E: Effusivity $\mathrm{W} / \mathrm{m}^{2} \mathrm{~K} \mathrm{~s}^{1 / 2}$

IN: Solar flux $\mathrm{W} / \mathrm{m}^{2}$

m: masse $\mathrm{kg}$

$\mathrm{S}$ : useful surface area of the collector $\mathrm{m}^{2}$

$\Delta \mathrm{T}$ : increase in temperature $\mathrm{K}$

$\Delta \mathrm{t}$ : Duration h

$\mathrm{T}_{\mathrm{a}}$ : Ambient temperature $\mathrm{K}$

$\mathrm{V}_{\mathrm{s}}$ : Volume of racking litter

$\mathrm{U}$ : Coefficient of the losses during the night $\mathrm{W} / \mathrm{m}^{2} \mathrm{~K}$

$\mathrm{V}$ : Speed of wind $\mathrm{m} / \mathrm{s}$

$\rho$ : Density of material $\mathrm{Kg} / \mathrm{m}^{3}$

$\alpha$ : Absorption coefficient of absorber

$\tau$ : Coefficient of transmission

$\eta$ : Efficiency

Cp: Specific heat of material $\mathrm{J} / \mathrm{Kg} \mathrm{K}$

D: Diffusivity $\left(10^{-6} \mathrm{~m}^{2} / \mathrm{s}\right)$

E: Effusivity $\left(\mathrm{J} / \mathrm{m}^{2} \cdot \mathrm{K} \cdot \mathrm{s}^{1} / 2\right)$

$\mathrm{U}$ : thermal loss coefficients $\left(\mathrm{Wm}-{ }^{2} \mathrm{~K}^{-1}\right.$ )

$\rho$ : Density of material $\mathrm{Kg} / \mathrm{m}^{3}$

$\lambda$ : thermal conductivity $\mathrm{W} \mathrm{m} \mathrm{m}^{-1} \mathrm{~K}^{-1}$

\section{References}

[1] Borello D. and all. Experimental and computational investigation of a new solar integrated collector storage system. Applied Energy(2012).
[2] Souliotis M. and al.Heat retaining integrated collector storage solar water heater with asymmetric CPC reflector. Solar Energy 85 (2011) 2474-2487.

[3] Smyth M., Eames P.C., Norton B. Integrated collector storage solar water heaters. Renewable and sustainable energy reviews 10 (2006), 503-538.

[4] K.S. Reddy Thermal modeling of PCM-Based solar Integrated Collector Storage Water Heating System. Journal of Solar Energy Engineering 129(4).

[5] Rabin Y, Bar-Niv I, Korin E, Mikic B. Integrated solar collector storage system based on a salt-hydrate phase-change material. Solar Energy 1995;55(6):435-44.

[6] Ben Slama R., "Experimentation of a plane solar integrated collector storage water heater". International Renewable Energy Congress IREC, Sousse Tunisia 5-7 November 2010. Pp 395-403.

[7] Ben Slama R., "Experimentation of a Plane Solar Integrated Collector Storage Water Heater". Energy and Power Engineering, Scientific Research 4, 2012, 67-76. Doi: 10.4236/epe.2012.42010.

[8] Ben Slama R., Chaouachi B., Gabsi S. "Etude et développement d'un chauffe-eau solaire type capteur à stockage intégré". ${ }^{\text {ème }}$ Congrès International sur les Energies Renouvelables et l'Environnement CERE, Sousse Tunisie 2426 mars 2005.

[9] Ben Slama R., Chaouachi B., Gabsi S“Experimental study of an integrated storage collector solar water heater under reals conditions". International Congress on the Engineering of Renewable Energies. HammametTunisie. 6-8 nov.2006.

[10] Ben Slama. "Comparative study between three solar water heaters according to the integrated storage type:water, sand and concrete. Machines Review. ISSN: 2408-9141 Vol. 1, No. 1, 28-33, 2014 http://asianonlinejournals.com/index.php/Mare.

[11] Labbou W., Jdaïda S. "Etude du chauffage de l'eau par l'énergie solaire à stockage intégré autre que l'eau", Départ.Electromécanique ISSAT Gabes Tunisie, juin 2013.

[12] Abdelmoumen R, Elghoul M. "Réalisation et essais de chauffe-eaux solaires à stockage intégré", Départ. Electromécanique ISSAT Gabes Tunisie, juin 2014.

[13] http://fr.wikipedia.org/wiki/Diffusivit\%C3\%A9_thermique.

[14] http://passivact.com/Infos/InfosConcepts/files/QualiteThermiq ue-ComparaisonsMateriaux.html.

[15] http://www.lanniontregor.com/files/CALT_39121_1332771037617_PER_BAT_1 08_fiche_INERTIE_03_02.pdf.

[16] http://entreprises.sigpyrenees.net/cours/cours1/co/p1s05_effusivite.html.

[17] http://www.diffusivitethermique.fr/. 